\title{
Back to the future, forward to the past: Croatian politics of memory in the European Parliament
}

\author{
Ana Milošević (D)* \\ Faculty of Social Sciences, University of Leuven, Leuven, Belgium
}

(Received 25 February 2016; accepted 15 August 2016)

\begin{abstract}
This paper discusses the way in which a post-conflict European Union (EU) member immediately after accession both shapes and adapts to EU memory politics as a part of its Europeanization process. I will analyze how the country responds to the topdown pressures of Europeanization in the domestic politics of memory by making proactive attempts at exporting its own politics of memory (discourses, policies, and practices) to the EU level. Drawing evidence from Croatian EU accession, I will consider how Croatian members of the European Parliament "upload" domestic memory politics to the EU level, particularly to the European Parliament. Based on the analysis of elite interviews, discourses, parliamentary duties, agenda-setting, and decision-making of Croatian MEPs from 2013 to 2016, I argue that the parliament serves both as a locus for confirmation of European identity through promotion of countries' EU memory credentials and as a new forum for affirmation of national identity. The preservation of the "Homeland War" narrative (1991-1995) and of the "sacredness" of Vukovar as a European lieu de mémoire clearly influences the decision-making of Croatian MEPs, motivating inter-group support for policy building and remembrance practices that bridge domestic political differences.
\end{abstract}

Keywords: European memory; enlargement; Croatia; MEPs; Vukovar

\section{Introduction: Europeanization and the politics of memory}

Apart from the power of memory to influence the present, there is also the power of present to influence the memory. (Müller 2002, 34)

Since the beginning of the process of European integration, the European Union (EU) has tried to foster shared norms, beliefs, and values in order not only to support its economic and cultural integration efforts but also to historically justify the project of EU integration. EU enlargement to the east "has accelerated the need for stronger mechanisms of identification with the EU as a political project," but "it has also represented an additional obstacle to the construction of a would-be European narrative which could fulfil this function" (Littoz-Monnet 2012, 26). Since 1989, the countries of Central and Eastern Europe (CEE) have had to deal with a history that includes not only Nazism and the Holocaust but also the Communist and Stalinist crimes (see e.g. Mink and Neumayer 2013). Therefore, existing memory discourses could not easily fit memory cultures of the new, postCommunist members that brought into the EU their own conflicting memories and their

*Email: ana.milosevic@ soc.kuleuven.be 
own need to cope with the past, awakening ideological struggles over "right" and "wrong" interpretations of history, eastern and western memories.

Over the last decade, the European Parliament has become one of the most significant "memory entrepreneurs"1 of a common European history and remembrance, moving from "the mere advocacy of symbolic politics to the active construction of shared European narratives" (Sierp and Wüstenberg 2015, 325). The EP took an active role in reconciling eastern and western historical narratives with a resolution on "European conscience and totalitarianism" (2009) and "European Day of Remembrance for the Victims of all Authoritarian and Totalitarian Regimes" offering a European reading of the past - an overarching, anti-totalitarian interpretation of European history (see e.g. Littoz-Monnet 2012).

With the establishment of an ideal- and value-based approach for promotion of reconciliation and a common view on history, a self-critical stance toward the past became a sort of EU "soft" entry criterion, particularly relevant for the post-conflict candidates striving to join the EU. The EU's expectations of post-conflict candidates and potential candidates (such as Bosnia and Herzegovina, Serbia, and Kosovo) are expressed not only via explicit demands embedded in EU conditionality (for instance, cooperation with the International Criminal Tribunal for the former Yugoslavia [ICTY]), but also via implicit requirements grounded in rapprochement, reconciliation of former enemies, and their "dealing with the past."

As a transnational memory entrepreneur, the European Parliament disseminates its discourses, memory policies, and practices: internally throughout the member states and externally, to outside countries. For example, in the EP's resolution on "European conscience and totalitarianism," explicit references to the historical experiences of the EU neighboring countries can be found (the Holodomor in Ukraine, Srebrenica in Bosnia and Herzegovina). By directing these policies at non-member states, the European Parliament generates soft pressure to conform/align with EU memory framework as a prescribed model. The asymmetrical nature of the process of Europeanization ("top-down") in the pre-accession stage seems to affect the ways in which political elites of potential member countries "use and abuse" collective memories. However, when the relationship between the actors is horizontal, EU members are not mere absorbers of EU policies, norms, and practices but active "uploaders" of their own policy preferences, practices, and narratives to the EU (see e.g. Börzel 2002, 2011 on Europeanization as a two-way process).

In a post-conflict setting, with the long-term processes of transitional justice and reconciliation unfolding parallel to Europeanization, bilateral war-related issues between former antagonists are potentially a complicating factor of EU enlargement. Residues of the past conflict, its disputed histories and memories could thus become a powerful foreign policy tool especially if one of the countries is a member state. If this were the case, candidate states would be compelled by member states into making concessions to advance on their EU path. Given that resolving bilateral issues in the enlargement process could affect the process of Europeanization and upset regional stability, it can be argued that it also deepens the existing divide between former antagonists, stimulating an anti-EU sentiment and nationalism; destabilizing outcomes contrary to those sought by the EU (Geddes and Taylor 2015, 3).

This paper scrutinizes how an EU member responds to the "top-down" pressures of Europeanization of the domestic politics of memory by making active attempts at exporting its own politics of memory (discourses, memories, and narratives) to the EU level. By "uploading" national preferences to the EU level - opposed to "downloading" policies from Brussels - EU countries seek to shape and influence the EU policies which they are subsequently obliged to follow (Börzel 2002; De Flers and Müller 2009, 5). Drawing on evidence from 
the post-accession of Croatia as the newest EU member, this paper seeks to analyze how and with what purpose Croatian MEPs are "uploading" memories of the Yugoslav war (1991-1995) and Vukovar ${ }^{2}$ (1991) as its main symbol to the European Parliament. Assuming that after EU accession, national memory politics is no longer under the constraint of the EU's expectations to adopt a self-critical stance toward one's own past, I anticipate a member state using the EP as an arena for the confirmation of its European identity, European memory credentials, and values. Due to the post-conflict nature of Croatia and as a consequence of the conditionality-based approach to coping with the war past (the international tribunal criteria), I would expect to find evidence of the mobilization of Croatian memory politics for the reaffirmation of national identity in the EU arena. Acting as a foreign policy tool for dealing with unresolved bilateral war-related issues with its neighbors (namely Serbia), the politics of memory is likely to support the integrity of the Homeland $\mathrm{War}^{3}$ narrative - which was questioned during the EU integration process.

My contribution starts by looking at the Croatian politics of memory in the EU enlargement process, its domestic "memory entrepreneurs" and their political discourse. Secondly, through the analysis of the parliamentary activities of Croatian MEPs between 2013 and 2016, I will analyze how Croatia, in immediate post-accession, both shapes and adapts to EU memory politics as a part of the Europeanization process. In particular, I examine: (1) commemorations, as mnemonic practices interwoven with symbolism serving thus, as an important element of identity-fostering; (2) political discourse of Croatian MEPs; and (3) policy building through resolutions, declarations, and amendments.

Primary data come from semi-structured core interviews with Croatian MEPs from the first (2013-2014) and the second mandate (2014-2019) in the EP and exploratory semi-structured interviews with their peers (such as the EP's rapporteur for Serbia), Croatian intellectuals, and journalists in Brussels. ${ }^{4}$ Secondary data relate to the role of memories in the parliamentary activities of the MEPs (2013-2016) and was collected through the EP's database (questions, motions, opinions, reports, speeches, and declarations). This dual approach enables a better understanding of the idiosyncrasy of the interplay between memory and politics in the activities of MEPs in the framework of the EP, producing a nuanced and empirically grounded picture of the role of the past in the European Parliament.

\section{Memory matters politically: Croatia between the Yugoslav past and a European future}

\section{The homeland war: Croatian post-Yugoslav memories}

Facing imminent threat of the country's dissolution and the outbreak of war in the early 1990s, Yugoslav political elites seized the momentum for the revival of politically useful national past(s). This process of the Balkanization of memory, or rather de-Yugoslavization, was encompassed by collective forgetting of a common history and simultaneously, the emergence of suppressed, ethnically colored memories of WWII. The Yugoslav, antifascist narrative ignored the ethnically motivated crimes of the Četniks, ${ }^{5}$ Ustaša, ${ }^{6}$ and Partisans ${ }^{7}$ during WWII, failing to provide "an accurate collective memory for all marginalized groups" (Radonić 2012, 205). Therefore, when the shared memory regime started eroding, it was readily substituted with a new narrative rooted in the historical continuity of a national statehood - able to support the independence claims of Yugoslav republics.

With the victory of the Croatian Democratic Union (HDZ) in the first free, multiparty elections (1990), President Franjo Tuđman anchored a new narrative in the idea of an "allCroatian reconciliation:" in his vision, Croatian Communists and Ustaša both fought for the same cause: Croatian independence. From being a WWII Partisan officer, Tuđman readily 
"converted to a revisionist historian and an extreme Croatian nationalist" who embraced the antifascist values of the Partisans' struggle while "renarrating the Ustaša past as a 'milestone to Croatia's independence"" (Radonić 2012, 206). Resistance movements and the National Liberation Army ${ }^{8}$ were banished from the "official" memory, despite a nationally proclaimed commitment to antifascism. Antifascist monuments and memorials were destroyed and removed, erasing the remaining traces of a Yugoslav past in the public space. Partisan actions against civilians and the Ustaša during the aftermath of WWII, as in the case of Bleiburg, ${ }^{9}$ were vested with a new meaning, becoming lieux de mémoire of a "Croatian Holocaust" (Prcela and Živić 2001), the victims of Tito's Communism. On the other hand, the number of Jewish, Roma, and Serbian victims in Jasenovac, the Ustaša concentration camp, were subject to minimization and the denial of responsibility for the crimes (Radonić 2012).

It was in this climate of historical revisionism that the quest for independence from Yugoslavia also became a path to a new Croatian identity, leading to the introduction of renegotiated narratives, remembrance practices, and state symbols of a symbiotic past-inthe-present. Observed through the prism of Tuđman's revisionism of WWII, the emerging Yugoslav war was the war for the homeland of reconciled Croatian people.

The Homeland War or the "war that is not allowed to be forgotten," played a crucial role in the official state- and identity-building narrative of Croatia (Jović 2012) focusing on the idea that "Croatia was attacked by rebellious Serbs and the Yugoslav People's Army, and that it defended its sovereignty and achieved independence by winning the war" (Banjeglav 2012, 10-11). The Homeland War was memorialized by state and non-state actors as soon as it had begun, in order to mobilize support for the war effort and government: to galvanize the majority ethnic community around a desired narrative of the war, and to attract international stakeholders to the Croatian interpretation of the conflict (Baker 2009, 35). Commemorating and celebrating the Homeland War thus aimed to construct the dominating and non-negotiable identity-building narrative that left almost no gaps for oppositional narratives of other groups, notably the national minorities (Banjeglav 2012). This becomes particularly evident in the case of Vukovar, which in the Croatian collective imagination represents a symbol of the 1990s war and the Croatian struggle for independence. However, as Banjeglav $(2012,16)$ reminds us,

\begin{abstract}
memory-making around Vukovar is more complex than it seems on the surface because it not only speaks of the past and the events that happened during the war but also reflects the present state of the Serb minority issue in Croatia, as well as bilateral relations between Serbia and Croatia.
\end{abstract}

\title{
The road to the $\mathrm{EU}$ via The Hague
}

Since independence, Croatian political elites have had mixed feelings about the EU: Tuđman was highly critical, especially because of the EU's lack of support to Croatia during the period preceding the destruction of Vukovar (1991) and its criticism of the impunity of the Croatian military for crimes committed in Bosnia and Herzegovina and Republika Srpska. The HDZ government was uncooperative with the ICTY, ${ }^{10}$ refusing to recognize its jurisdiction over the Oluja (Storm) and Bljesak (Flash) ${ }^{11}$ military operations and stalling the extraditions of Croatian nationals to the ICTY, located in The Hague. By mid-1999, with Croatia facing possible international sanctions due to the government's foot-dragging, the main opposition party, the Social Democrats (Socijaldemokratska partija Hrvatske - SDP), began openly accusing the HDZ of leading the country into isolation on the international stage. 
After Tudjman's death in 1999, the EU launched the Stabilization and Association Process, imposing region-specific prerequisites for EU integration, including full cooperation with the ICTY. The point of the EU political conditionality was to pressure political elites to start dealing with Croatian war crimes, redefine their national orientation toward an EU future, and work on regional reconciliation by breaking all ties with the nationalistic heritage. These expectations became the "acquis of European values," and seriously threatened official exculpating historical narratives of the 1990s war in which "Croatia is perceived only as the victim" (Jović 2009, 20) and not the perpetrator of Balkan wartime atrocities.

Led by Ivica Račan (SDP), the block of parties of a left and centrist orientation ${ }^{12}$ won the elections in early 2000 , ending 10 years of rule by the HDZ. Račan's coalition government promptly addressed the ICTY contested issues, ${ }^{13}$ facing harsh public reaction and triggering protests led by the HDZ, retired generals, and the Croatian Military Invalids of the Homeland War between 2000 and 2002. Stjepan Mesić, elected the second president of Croatia, had to intervene and dismiss 12 high-ranking officers, among them Ante Gotovina, ${ }^{14}$ for openly intervening in matters of state and criticizing the government's policy toward the ICTY. Mesić openly opposed Tuđman's revisionism, his ideas on an "all-Croatian reconciliation," and the falsification of history by condemning "the crimes committed in the name of the Croatian state, including not only the ones in the Jasenovac death camp, but also those from the more recent past" (Radonić 2012, 210).

The EU requirements divided the Croatian political spectrum: the SDP-guided government pushed for compliance with the ICTY demands, distancing the country from 10 years of historical revisionism. On the other hand, HDZ strived to resist the external demands by hesitating to engage in a critical assessment of the Croatian role in the 1990s war. Tuđman's successors in HDZ developed a strong rhetorical strategy depicting the ICTY's indictments against Croatian war heroes as an attack on the sacredness of the Homeland War (Jović 2009) and the ICTY as a biased and unreasonable attempt "to undermine the authority of the Homeland War" (Jović 2012, 68). The media-savvy HDZ used its political clout to gain popular support for the elections in 2003, loudly defending the legitimacy of the Homeland War and building upon positive national self-imaging by excluding any selfcriticism on the Croatian role in the war. Nevertheless, after a convincing electoral victory the HDZ took an unexpected turn: it sought to create a more receptive environment in which the EU conditions could work, focusing on ICTY compliance and the EU's expectations of Croatia.

The informal "Pact for Europe" in 2003 managed to unite the two biggest parties: the ruling HDZ and the opposition SDP, making the EU orientation of Croatia the only viable future. The country began moving quickly ahead in its EU integration process. Croatia became the leader in the region working to improve, most notably, economic relations with its neighbors (such as through the Central European Free Trade Agreement) and pursuing a new policy of regional cooperation aimed at easing relations primarily with Bosnia and Herzegovina and, later, with Serbia. Nevertheless, even with a strong consensus among the parties on a future within the EU, compliance with the ICTY demands remained contested. As Jović $(2009,22)$ argues, this road led "via the capitals of the neighboring countries: primarily Belgrade and Sarajevo," but the first milestone on the road to the EU had to be The Hague.

The EU decided to open accession negotiations in mid-2004, but they were quickly postponed because Brussels insisted that Croatia engage in "full cooperation with the ICTY" and deliver indicted General Gotovina. For many Croatian citizens, Gotovina was a war hero and a martyr to a European future: he not only represented "the generals 
of Croatia's victorious army, but the Homeland War, Croatian sovereignty, the Croatian state, and ultimately all Croats" (Pavlaković 2010, 1717). Hence, the EU pre-conditions challenged not only Croatian national identity (see e.g. Freyburg and Richter 2010 on the ICTY Conditionality in the Western Balkans), which was embedded in a one-sided narration of the Yugoslav war and its heroes, but was also perceived as a direct attempt to rewrite history and question the legitimacy of the war.

The enforcement of the EU pre-conditions threatened domestic political stability and spurred anti-EU sentiment and nationalism. A Eurobarometer survey in 2005 (EB 63) found fewer people in Croatia who felt "European" (57\%) than in the EU overall $(66 \%)$ (EP 2005). Public support for EU membership was decreasing (only 27\%) and Euroscepticism was rising: only $58 \%$ of Croats expressed trust in the EU, the second-lowest score after the UK (53\%). These attitudes were largely fueled by the complicated relationship with the ICTY but also by disputes with EU members Slovenia and Italy. ${ }^{15}$

However, political elites publicly supported full cooperation with the ICTY. Two narratives emerged in their political discourse as counter-arguments to the rising public discontent. The first, "the return to Europe," was a bit of rhetoric prevalent in other CEE countries after the fall of Communist regimes and their own EU accession. "Returning to Europe" meant that Croatia was and continued to be a European country, thus its place was with the "European family of nations." The second narrative evoked the regionally used and abused Antemurale Christianitatis myth in which Croatia was represented as the last frontier of Europe and historical defense line against the Ottoman conquest. Both narratives were strongly rooted in the past, geared toward the future, and used by political elites for their present political needs. Their discourse revealed not only a determination to join the EU and a quest for Croatian Europeanness but also a shift from Tudjman's historical revisionism and conception of Croatianness in contrast to Serbs and the Balkans, to a Croatian European identity and a European homecoming. The Balkans were the past to leave behind, and EU membership was the future to embrace.

As Schimmelfennig $(2008,928)$ explains, Croatia was in an "endgame of highly credible political conditionality" and possible benefits from the start of negotiations prevailed over the costs. When Gotovina was finally captured in December 2005, Croatia officially fulfilled the "ICTY condition" and the negotiations were unblocked. Two intertwined narratives of Croatian Europeanness: "the last European outpost" and "the return to Europe" as an expression of European credentials and values of Croatia were tested in Croatia's EU referendum in January 2012. When, at the end of 2012, the ICTY overturned the convictions of Croatian generals for the expulsion of ethnic Serbs during Operation Storm in 1995, the ruling was welcomed as an exoneration of Croatian war-sins. In the words of President Ivo Josipović (SDP), the verdict confirmed "everything that we believe in Croatia: that generals Gotovina and [Mladen] Markač are innocent" (The Guardian 2012).

\section{Post-accession of Croatia and the European Parliament}

Croatia's accession to the EU in 2013 was a long and arduous process of meeting EU demands and expectations that tested not only compliance with the acquis communitaire but also the democratic maturity of society and its political elites.

The first European elections were held in Croatia on the eve of accession, on 14 April 2013. The maximum number of MEP seats was provisionally raised to 766 , in order to accommodate the 12 new Croatian members. The first term showcased the balance in distribution of seats between Croatia's two major political parties: five MEPs came from the HDZ (a member of the European People's Party, or EPP) and its allies, and five from the 
SDP (in the EP's Socialists and Democrats group [S\&D]) and its allies. The remaining two seats were won by a member of the Labor Party (Hrvatski Laburisti-stranka rada in the European United Left - Nordic Green Left group) and a candidate from the right-wing Party of Rights (Hrvatska stranka prava - European Conservatives and Reformists [ECR]). These MEPs had a 10-month mandate until the next regular EP elections in 2014, when the number of Croatian seats was cut to 11 .

In Croatia's second European Parliament elections, voters chose four MEPs from the HDZ, two from the SDP, and one each from the Croatian Conservative Party (Hrvatska konzervativna stranka HKS - ECR), the Croatian Sustainable Development Party (Održivi razvoj Hrvatske - Greens/EFA), the Croatian Peasant Party (Hrvatska seljačka stranka HSS - EPP), the Croatian People's Party (Hrvatska narodna stranka in the Alliance of Liberals and Democrats for Europe [ALDE]), and the Istrian Democratic Assembly (Istarski demokratski sabor, also in ALDE). In terms of EP party affiliation, five of Croatia's MEPs come from the EPP, two from S\&D, two from ALDE, and one each from the Greens and the ECR. Seven MEPs from the first mandate in the EP were re-elected (2016).

Being the first post-conflict Balkan country to join the EU has given Croatia a stronger say in the region, especially toward candidate countries from its own back yard. Of Croatia's MEPs, three are members of the delegation working with Macedonia; five are in the delegation working with Bosnia and Herzegovina and Kosovo, including Tonino Picula (S\&D) as chairman and Dubravka Šuica (EPP) as vice chairwoman; one is in the delegation working with Albania; and another in the delegation for Montenegro. Three MEPs act as substitutes in the delegation dealing with Serbia. Andrej Plenković (HDZ-EPP) is vice chairman of the influential Foreign Affairs Committee.

The interest of Croatian MEPs without any doubt lies in its "near abroad." From the distribution of seats and functions of Croatian MEPs in the EP's committees and delegations, it becomes clear that political positioning of Croatia in the EP revolves around the former Yugoslav republics and other Balkan states, notably Albania and Kosovo.

\section{Confirming Croatian EU memory credentials: Vukovar as a European lieu de mémoire}

In September 2013, just a few months after Croatia joined the EU, a political earthquake shook the country with demonstrations in Vukovar when protesters, both civilians and the war veteran members of the Committee for the Defense of Croatian Vukovar (i.e. Stožer ${ }^{16}$ ), tore down signs on governmental buildings that were written in both the Latin and Cyrillic Serbian alphabet. ${ }^{17}$ The demonstrations continued for several days, with protesters opposing the introduction of signs in Serbian, resulting in the arrest of several Stožer members. Two months later, the Vukovar City Council banned the official use of the Cyrillic alphabet and exempted the city from the State Law on Protection of Minorities. Vukovar was declared "a place of special reverence" because of what the city suffered under siege by Serbian forces in 1991, as a "trauma experienced by the Croats in Vukovar during the war is still too strong to respect the rights of the Serbian minority in the city" (Pavelić 2013).

Against this background, Vukovar - "a hero-town" - became the first domestic memory exported to the European Parliament by Croatian MEPs in the immediate post-accession. The group of HDZ MEPs, guided by the ideas of MEP Davor Ivo Stier, organized a commemoration in order to express their "gratitude toward all who enabled freedom to Vukovar and Croatia today, in a united and reconciled Europe" (HDZ 2013). The event was the HDZ's own homage to Vukovar Remembrance Day, presenting a project organized for 
the Croatian Youth: an essay competition on the meaning of Vukovar (Stier 2015, Interview). "The most salient symbolic representation of the tragic 1991 event was: 'Vukovar, city of peace,'" Stier recalls (2015, Interview). However, the accompanying exhibition: "Vukovar city, the hero" showcased photographs of "the city victim of two joint totalitarianisms - Communism and Serbian fascism, ideas that inspired the attack on Vukovar, therefore the Remembrance Day of Vukovar victims is important not only for Croatia, but for the EU" (HDZ 2013).

One of the interpretative keys used to give a European reading of Vukovar and promote this national lieu de mémoire in the EP is the "European conscience and totalitarianism" policy. For the organizers, Vukovar commemoration is a part of broader EU remembrance initiatives since "Vukovar has a special place in [our] history; it cannot remain solely as a reminder of suffering (...). Because of Vukovar, Croatia, and Europe, I would like Vukovar to become a sort of Strasbourg, in a broader European context" (Stier 2015, Interview). In comparing Franco-German relations after WWII with the war in 1990s in the Balkans, Stier (2015, Interview) explains the importance of Strasbourg/Vukovar:

When Germany convinced everybody that they seriously condemn[ed] Nazism, Alsatian authorities used Strasbourg not only as a symbol of suffering, but as a symbol of peace and reconciliation.

In the EP, Vukovar is narrated in "a European way:" as a symbol of peace and reconciliation and as the victim of not one but "two joint totalitarian regimes" (HDZ 2013) and as such, according to HDZ MEPs, deserves a space in European memory. The heroic victimhood of Vukovar thus symbolizes not only the Croatian price for independence but also its Europeanness, its contribution to an anti-totalitarian struggle.

If, in the first Vukovar commemoration in the EP, the main "memory entrepreneurs" were MEPs from the HDZ party, in 2014 and 2015 other Croatian MEPs joined their initiative remembering the (Croatian) victims of Vukovar. The approach taken by the organizers was also different. Instead of organizing an exhibition as in 2013, the 2014, and 2015 commemorations included a prayer for the victims said by a Catholic priest. Vukovar and, since 2014, Škabrnja ${ }^{18}$ were commemorated as symbols of Croatian freedom and resistance during the Homeland War, honoring Croatian civil and military victims.

Two readings of Vukovar emerge in the speeches and declarations by Croatian MEPs during three consecutive commemorations (2013, 2014, and 2015). On the one hand, Vukovar is narrated through its heroic victimhood as a European symbol of peace and reconciliation. This is realized in the discourse of all Croatian MEPs. The focus of this narrative is on "learning from the past" and "looking toward the future." The SDP MEPs are concerned with rebuilding "Croatian and European Vukovar as a reminder of the contribution that the city made to Croatian freedom and the European togetherness in that freedom" (Dnevnik 2014). They look to Picula's idea of making Vukovar the seat of an EU agency. MEPs coming from less-represented parties such as Održivi razvoj Hrvatske (The Greens) believe that "remembrance is important" yet they are more concerned with "the future, youth, and unemployment problems rather than with the past" (Škrlec 2015, Interview). On the other hand, the HDZ's discourse revolves around Vukovar as a "European lieu de mémoire" with focus on the transmission of war memories and its actors, selective remembrance ("Croatian civil and military victims") and "values for which the veterans fought," at the EU level and for posterity, in particular for Croatian youth.

At home, the annual Commemoration of Vukovar "tirelessly promotes the message that the past must never be forgotten, thereby helping to ensure that particular memories of the war remain fresh and emotions remain raw" (Clark 2013, 119) and so, too, does it in the EP. 
Despite the rhetoric of reconciliation and forgiveness, Vukovar commemorations in the EP do not suggest reconciliation of any kind: they serve as a display of pride and an expression of national identity, shaping European perceptions of the righteousness of the Homeland War and Croatia as the victim of totalitarian regimes throughout its history. Through the narration of the tragic past of Vukovar, HDZ MEPs have become its main memory entrepreneurs; "uploading" the message that not only was Vukovar the victim of the Yugoslav war but also that Croatia itself was a victim of Yugoslavia and Serbia, old ("Communist") and new ("Serbian fascism") totalitarian regimes. Dubravka Šuica, one of the most ardent HDZ MEPs, illustrates the importance of Vukovar commemorations in the EP and the transmission of these memories to posterity:

It's nice that the day of remembrance of the victims of Vukovar and Škabrnja is celebrated every year growing into a tradition so that the light of Vukovar shines in Brussels. All this is in line with a prayer that says: "We should not gamble with the values for which our veterans fought." I believe that we will succeed and that we have managed to convey that message to our young people, because by remembering the victims of Vukovar and forgiving we can experience reconciliation and build the future of Croatia. (Večernji list 2015)

During the 2015 Commemoration of Vukovar in the EP, Andrej Plenković (HDZ) drew attention to the "Croatian civil and military victims" of the Homeland War, evoking Tuđman as a visionary of Croatia's European future in peace:

On behalf of all 11 Croatian representatives in the EP, today we are here in the center of the European institutions celebrating the Day of Remembrance of the victims of Vukovar and Škabrnja, symbols of the Homeland War, Croatian soldiers and civilians, of all those who gave their sacrifice for the future of European Croatia. We remembered the words of the first Croatian president, Dr. Franjo Tuđman, during the peaceful reintegration of the Croatian Danube region, who pointed out that peace, co-existence, and reconciliation are in Croatia's general interest but also in Europe's interest. In this context, we want the young generation here in Brussels to have a constant evocation and remembrance of those who gave their lives for Croatia. (Večernji list 2015)

It can be argued that for Croatian HDZ MEPs, raising awareness of the Homeland War is as important as paying tribute to the veterans who fought for Croatian independence. The HDZ uses Vukovar to reconfirm the legitimacy of the Homeland War and the role of its actors, which was seriously threatened during the EU accession process, through the ICTY component of the acquis. The veterans are frequently recalled and described as "liberators," "defenders," "heroes," and "victims," reminding the EP of their contribution to Croatian independence and comparing the Yugoslav past of Croatia with the "oppressive" Communist regimes in CEE. In their vision, Croatian return to the European family of people came "after demanding reforms, but above all thanks to the sacrifice of Croatian Defenders in the Homeland War" (Plenković in EP 2014a).

Deep divisions at the domestic political level and the difficult relationship between political elites and Stožer, who claim the right to be the sole guardians of the memory of Vukovar, demonstrate how important the memories of the war are in Croatian politics. "If it weren't for Vukovar, Croatia would not exist," says General Ivan Cermak, ${ }^{19}$ another veteran who in 2013 together with Gotovina and Markač ${ }^{20}$ accompanied Stožer in a commemorative Vukovar march (Večernji list 2013). If once seen as war heroes and martyrs to a European future for Croatia, the acquitted generals now seem more like political figures whose presence in political or commemorative events adds value and carries powerful symbolism (Pavlaković 2010).

While commemoration of Vukovar in the European Parliament addresses a different audience, the presence of war veterans in the EP is as important for the HDZ as in 
Vukovar. In the week of the first Vukovar commemoration in the EP in 2013, Suica (HDZ) proposed to MEP Martinez, the EP's vice president, “to host and meet in Strasbourg, 29 veterans of the Homeland War from Croatia ..." (EP 2013). After their visit to Strasburg in 2013, the veterans went to Brussels in 2014, while in 2015 they were just mentioned in the speeches delivered by Croatian MEPs.

It becomes clear that HDZ's sense of belonging to Europe relies on the EU's appreciation and understanding of the Croatian war experiences. We can see how they "upload" domestic politics of memory in the EP, more precisely, the Homeland War narrative and its most important symbolic lieu de mémoire: Vukovar. The absence of war veterans in the 2015 commemoration of Vukovar and the attendance of all Croatian MEPs, regardless of their political orientation, sent two important messages. The first, as Ivan Jakovčić (2015 Interview) from Istarski demokratski sabor (ALDE) points out, was to demonstrate that Vukovar can bridge "domestic political differences." Secondly, that there was an attempt to separate the military element of this narrative from the commemoration of victims, making it more receptive and more fitting in the European dimension. The role of the veterans, thus, is not belittled but rather made less central, at least in the EP.

The symbolic meaning of Vukovar in the EU arena is twofold: as a martyr, (the victim of "red and black totalitarian regimes") and as a European lieu de mémoire, (a symbol of peace and reconciliation). However, despite the rhetoric, the commemoration of Vukovar in the European Parliament does not show any evidence of reconciliation with the Serbian community of Vukovar; instead it acknowledges the European importance of the "Croatian struggle for independence" (the Homeland War) and its actors (veterans). Vukovar as a fundamental locus of memory becomes central for the display of national identity. By providing their own "European" example of victimhood as well as their own European locus of remembrance, these MEPs seek to confirm Croatia's European memory credu :itials.

\section{“Uploading” memory preferences and shaping the EP's policies}

While memories of the Homeland War are being brought into the EU arena as a way to satisfy identity needs and claims, their potential is recognized also as a tool for foreign policy. Among the interviewed Croatian MEPs, there is a clear consensus on the most important historical events vis-à-vis its European membership: "[the] relations between Croatia and Serbia, the Homeland War, and everything that happened in the 1990s" (Stier 2015, Interview). Key bilateral issues are residues of the war in the 1990s: borders, lustration, reparations, national jurisdiction in persecuting war crimes, missing persons, as MEPs Jozo Radoš, Ruža Tomašić, and Stier agree. Nevertheless, evidence suggest that these issues are tackled in the EP by leaning on Serbia, thus reaffirming Croatian influence on its future.

The most striking example of the mobilization of Croatian MEPs is their joint motion for a resolution on Vojislav Ššelj in 2014, as a reaction to the ICTY's temporary release of the Serbian politician accused of war crimes. After returning to Belgrade from The Hague, Šešelj held a public gathering where he made inflammatory statements, including congratulating 'Serbian Četniks on 'the release of Vukovar,' the event that Croatians commemorate as the anniversary of 'the fall of Vukovar"" (Večernji list 2014).

The resolution on Šešelj was initiated by the delegation of Croatian MEPs. Those from the EPP said the purpose of the resolution was to "remind Serbia of its obligations toward the ICTY and the EU, as candidate country;" the Socialists wanted to "condemn hate speech and Šešelj's insults toward all victims of the wars in ex-Yugoslavia, including the shameful 
statement made on the Remembrance Day for the victims of Vukovar" (Borzan, Personal communication, 4 June 2015); and the Greens wanted to send the message that "minorities, whether national or sexual, should be protected" (Škrlec 2015, Interview). However, from the discussion that followed in the European Parliament, the intention of the Croatian MEPs was not clear: were they judging the work of the ICTY, which liberated, albeit temporarily, ${ }^{21} \breve{S}$ ešelj, or were they criticizing the Serbian government for not "proactively supervising Šešelj's political statements" and distancing itself from his political "media spectacles" (Tomašić in EP 2014b)?

Šešelj's statements in Serbian media were perceived by Croatian MEPs as "an insult to the collective memories of Croatian citizens" (Škrlec 2015, Interview) and "historical revisionism" and "propaganda for Greater Serbia's expansionism" (Tomašić in EP 2014b) that "Croatia, the European Parliament, and the EU had to condemn" (Tomašić 2015, Interview). This implies that Croatian MEPs felt obliged to defend national collective memories (Sabalić 2015, Interview) and that Serbia, the EU, and the ICTY had to condemn Šešelj's "war-mongering rhetoric" in the name of "acceptance and sharing of European values, democracy, and progress of Serbia" (Maletić [HDZ] in EP 2014b). On the other hand, while Serbian Prime Minister Aleksandar Vučić called the resolution "an insult to Serbia" hiding "hypocrisy or a desire to harm the country" (Vijesti 2014), the European Commission assumed the position of non-interference with the ICTY's decisions (EP 2014b). In addition, the resolution's proposals were criticized by Croatian MEPs' peers in their own political groups in the EP as needless and "not a good place to give instructions to the ICTY by giving to this accused war criminal more attention than he deserves" (Kukan [EPP] in EP 2014b). Yet, as one of their peers from the EPP group explains, "This topic was of major importance for Croatian MEPs, and compromises inside the EPP had to be made" (MEP EPP 2015, Interview).

Clearly, memories of the Homeland War can still influence the decision-making of Croatian MEPs, who inside their political groups raised awareness of the importance (for the Croatian delegation) of this topic and gathered support for the preparation of the resolution. The decision of Croatian MEPs to react to Šešelj's release was also linked to their notions of the purpose and success of the ICTY in "imposing justice" on the post-war Balkans. Tomašić, a vocal advocate for the condemnation of Šešelj's statements in Serbian media and a critic of the ICTY, said the "incredible inefficiency and partiality of the Hague Tribunal is surprising and disappointing. Its historic mission has not been fulfilled. Rather, it has only brought additional turmoil to the countries [of the former Yugoslavia]" (EP 2014b). While the success of the ICTY on regional reconciliation and justiceseeking is considered "dubious" (Tomašić 2015, Interview), the tribunal is perceived as "not free of political interference" (Jakovčić 2015, Interview) - the critique that was heard so often during Croatia's EU accession and Gotovina's trials. By standing in defense of collective memories of the people of Vukovar and shielding the integrity of the Homeland narrative in this way, Croatian MEPs are reaffirming their national identity.

\section{Forward to the past: political discourse of Croatian MEPs}

When in March 2014 an exhibition of Croatian artwork was presented in the EP, Parliament President Martin Schulz wrote an opening message for the brochure, stressing "the unique position of Croatia in the former Eastern bloc, in the former Yugoslavia as a nonaligned country, and as a special place between West and East, not only in political and economic, but also in an artistic sense" (HR Svijet 2014). Croatian HDZ MEPs were furious and immediately wrote an open letter to the president asking for an explanation on "why a 
thousand-year-old Croatian cultural identity was neglected in his speech, which focused only on Croatian Yugoslav experience" (HR Svijet 2014).

For European Croatia, particularly in the discourse of HDZ's MEPs, the Yugoslav past is a burden: the EP serves as an arena to reinterpret the Croatian Yugoslav past by equating the post-1945 Croatian history under Tito to the experience of CEE under a totalitarian, Communist regime. On occasions, such as the anniversary of the fall of the Berlin Wall, which has a strong symbolic value in the history of reunited Europe, HDZ MEPs seek to raise awareness of Croatian historical experiences, situating them in a broader European context:

With the fall of the Berlin Wall, the most powerful symbol of the dissolution of the Eastern Bloc, the world was radically changed, but also changed was the view of the global public on Communism and the Communist system, and it created conditions for democratization and the removal of the Iron Curtain from north to south in Europe. Since I come from Croatia, which was under Communism for 45 years, I sympathize with and understand the fate of people who lived under the auspices of the totalitarian systems across Central and Eastern Europe. (Šuica in EP 2014a)

In the discourse of the HDZ MEPs, however, there seems to be no clear line between "Communism and fascism," then and now - WWII and the post-1945 Yugoslav past are used to interpret both the Homeland War and the current state of Croatian relations with Serbia.

On the eve of Croatia's entry into the EU, the message from Zagreb was that Croatia aspired to overcome preaching to its neighbors by offering them assistance and sharing the knowledge gained from its own accession. In the end, Croatia itself suffered similar pressures from neighboring Slovenia due to unresolved issues ${ }^{22}$ that hindered Croatia's path to the EU. David McAllister, a German politician who is the EP's rapporteur for Serbia, is

not so convinced, as an MEP, that it is always a clever move to bring bilateral issues between member states and not-yet-member states to the European Parliament. Usually we try to deal with the issues that concern the whole [of] Europe. (2015, Interview)

Yet Croatia seems to be asserting its "right" to use the EP as a platform for resolving bilateral, political, and historical issues with its neighbors.

Stier (2015, Interview) believes that to join the EU, Serbia will need to "deal with the past of its totalitarian regimes and face the dark pages of its own history." But some of his HDZ colleagues have more concrete expectations. "The past is a burden that Serbian authorities will have to face if they want to become part of the European family" Suica argues (EP 2015b). She explains what needs to be addressed:

the missing persons, the opening of the archives of the former Yugoslavia and the Yugoslav People's Army, the return of stolen artwork, the border on the Danube, the rights of national minorities, as well as the abolition of the controversial law on universal jurisdiction for war crimes in the former Yugoslavia. (EP 2015b)

Some of the main battlefields for memory in Croatian relations with Serbia are the Foreign Affairs Committee and the plenary sessions, where memories are mobilized as a foreign policy tool. During preparation of a 2014 resolution declaring the EP's opinion on Serbia's progress toward accession, Croatian MEPs “tested their 'firepower' against candidate Serbia" (Euractiv 2015), requesting that the country "amends its law on the prosecution of war crimes in order to prevent Serbian prosecutors from investigating and bringing indictments for crimes in the territory of the former Yugoslavia" (Petir in EP 2015a). Marijana Petir accused Serbia of unjust prosecutions, referring to the case of Veljko Marić, a Croatian fighter who was sentenced by a Serbian court to 12 years in prison in 2012 for 
killing an ethnic Serb civilian in October 1991 in the Croatian village of Rastovac (Ristić 2015). In addition, Petir demanded that the European Commission make it a condition of Serbia's accession that Belgrade amend "the Law on Organization and Jurisdiction of State Authorities in War Crimes Proceedings" (EP 2015a).

In December 2015, Croatian MEPs made an incredible 190 written amendments on the 2015 resolution on Serbia, accusing McAllister of being "too friendly" with Serbia and urging Serbia to "better protect national minorities, re-examine the rehabilitation of Draža Mihajlović ${ }^{23}$ and political interfering of the Serbian Orthodox Church, rethink its partnership with Russia, change the disputed law on war crimes, and speed up resolution of bilateral disputes with Croatia" (Večernji list, 2016).

Serbian reworking of the WWII past, in particular the rehabilitation of the wartime general Mihajlović, is considered by Stier (2015, Interview) "a step back." Mihajlović, an early leader of the fight against the Axis powers, has been accused of promoting the Great Serbia philosophy that was brutally taken up decades later by Slobodan Milosevic.

In addition, opening the files of Serbia's Yugoslav-era secret services is of particular interest to the region, most notably to the HDZ MEPs who believe that "the Communist crimes are not yet sufficiently studied nor researched" (Stier 2015, Interview).

Clearly, Croatian HDZ MEPs, their EPP partner Croatian Peasants Party (HSS), and the right-wing Croatian Conservative Party (HKS) are using the EP to put pressure on candidate country Serbia in order to find a favorable solution to existing bilateral issues. This complicated relationship evidences a power imbalance due to Croatia's EU membership and Serbia's EU aspirations.

"The acknowledgement of one's own 'dark' past, must not serve for payback, but 'selfcleansing,' a catharsis that enables a more open society, ready and prepared to build Europe together" Stier argues (2015, Interview). This inner "dealing with the past" as a prerequisite for joining the EU "was expected also from Croatia during its accession" (Tomašić 2015, Interview) and for Croatia, this was the "unjust" ICTY component of EU accession.

The ICTY has tried to balance the culpability of Serbia and Croatia, which are not even close. Croatia has no reason to deal with the past - there were some cases of inconsistencies in the actions of some military forces, which are to be condemned certainly, but for Croatia this process of coming to terms with the past is not catharsis nor traumatic, Radoš argues. (2015, Interview)

But according to Jakovčić (2015, Interview),

Like Serbia, the whole region has to deal with the traumatic past of the 1990s. Croatia has to find the courage to say that other innocent victims who were in the path of the advancing military died. The court has to establish what were crimes and prosecute those responsible

adding that "what truly matters is that countries, Serbia and Croatia, are now allies in creating and maintaining stability in the Balkans. Time will heal the wounds."

\section{Concluding remarks}

Croatia's post-accession period tells us that the paths toward regional reconciliation, truth, and justice-seeking are not necessarily cleared by the successful outcome of the EU integration process. Croatia fulfilled conditions set by the EU, including full cooperation with the ICTY, which gave the necessary push to a societal debate on the country's conduct in the 1990s war. If for the sake of attaining a European future major political parties stood united by resolving not to interrogate the past, today their representatives in the European Parliament seem more oriented toward the past than toward the future. 
Since the EU accession of the country, the HDZ (as the most represented Croatian party in the European Parliament) is the main "memory entrepreneur," "uploading" national memory politics to the EU arena through commemorations, policy building, and political discourse. The Homeland War memories - its lieux de mémoire, symbols, narratives, and actors, including veterans and Croatian civilian and military victims - are narrated in "a European way" and likened to the experiences of CEE under Communism and Western Europe under fascism. The EU arena is perceived both as a locus for the confirmation of European identity through the promotion of Croatia's European memory credentials and as an arena for the preservation of the integrity and sanctity of the Homeland War.

Post-accession Croatia also tells us something new about the Europeanization process: that "dealing with the past" should still be considered a key dimension of the EU enlargement agenda in the Balkans and other post-conflict settings. The memories of the 1990s war are still vivid and the processes of reconciliation and truth- and justice-seeking are far from done.

\section{Acknowledgements}

Part of the research for this article was conducted during a fellowship at the German Institute for Foreign Affairs and Security in Berlin and Brussels. I would also like to thank Heleen Touquet and anonymous reviewers for their feedback on earlier drafts of this article.

\section{Notes}

1. As those "who seek social recognition and political legitimacy of one (their own) interpretation or narrative of the past, engaged and concerned with maintaining and promoting active and visible social and political attention on their enterprise" (Jelin 2003, 33-34).

2. The Battle of Vukovar was an 87-day siege of the city by the Yugoslav People's Army from August to November 1991. When Vukovar fell on 18 November 1991, hundreds of soldiers and civilians were massacred by Serb forces and thousands of civilians were expelled from Vukovar.

3. In Croatia, the Yugoslav war is referred to as the War for Independence, for the Homeland.

4. The questions revolved around five main themes: (1) role of the EU in reconciliation and "dealing with the past" in Croatia and the Balkans; (2) The Homeland War narrative: uses of the past, statebuilding, and identity-building; (3) the ICTY and the EU accession of Croatia; (4) issues with Serbia; (5) memory and parliamentary activities of Croatian MEPs: agenda-setting, prioritizing, and decision-making. All interviews were held in Croatian and English.

5. The Četniks were a Serb nationalist movement led by Draža Mihailović during WWII. Initially fighting against the German occupiers and supporting the London-exiled Yugoslav royal family, Cetnik units started committing massive crimes against Croat and Muslim civilians in Croatia and Bosnia and Herzegovina while collaborating with Italians and Germans.

6. The Ustaša were a radical Croat nationalist organization established by Ante Pavelić in 1929. Influenced and supported by Fascist Italy and Nazi Germany, they created the Independent State of Croatia (NDH - Nezavisna država Hrvatska). Throughout WWII, Ustaša were responsible for mass murder, concentration and death camps, and systematic persecution of nonCroat civilians, most notably Serbs, Roma, and Jews.

7. The Partisans were a Yugoslav Resistance movement led by the Communist Party of Yugoslavia during WWII under the command of Josip Broz Tito.

8. The term used to define the Yugoslav resistance that fought for liberation from the Nazi and Fascist occupation.

9. The mass killing of members of the Axis defeated forces by the Partisans in the immediate aftermath of the war in Bleiburg (Austria).

10. One of the first crises was the Blaškić case, when the chief prosecutor requested documents related to the case and the Croatian government refused to hand them over. 
11. The Bljesak (Flash) and Oluja (Storm) military campaigns took place in 1995, resulting in a massive exodus of the civilian ethnic Serb population.

12. SDP (Socijalno-demokratska stranka - Social Democrats Party), HSLS (Hrvatska Socijalno Liberalna Stranka - Croatian Social Liberal Party), and HSS (Hrvatska Seljačka Stranka - Croatian Peasant Party) became the three biggest partners of a coalition government of six political parties, together with HNS (Hrvatska Narodna Stranka - Croatian People's Party), LS (Liberalna Stranka - Liberal Party), and IDS (Istarski Demokratski Sabor - Istrian Democratic Parliament).

13. See, for example, Deklaracija o suradnji s Međunarodnim kaznenim sudom u Den Haagu (2000).

14. Ante Gotovina is a retired Croatian general who was indicted by the ICTY on charges of war crimes and crimes against humanity in connection with Operation Storm. He was captured in the Canary Islands in December 2005, after four years in hiding.

15. Dispute with Slovenia over Piran Bay and Italy over an ecological and fisheries protection zone.

16. An umbrella organization of veterans' associations.

17. In accordance with the European Charter for Regional or Minority Languages and the Croatian Law on National Minorities, bilingual signs must be displayed in areas where more than one-third of the population belongs to an ethnic minority.

18. The Škabrnja massacre happened on 18-19 November 1991 in the villages of Škabrnja and Nadin. Croatian civilians and prisoners of war were killed by Serbian Autonomous Oblast Krajina (SAO Krajina) Territorial Defense troops and the Yugoslav People's Army.

19. Indicted in front of the ICTY on charges of crimes against humanity and of operating a joint criminal enterprise for the purpose of permanently removing the Serb population from the Krajina by force, he was acquitted in 2011.

20. Gotovina and Markač were freed in 2012 when the ICTY overturned their war-crimes convictions. Their release led to nationwide celebrations in Croatia and anger and disbelief in Serbia, which accused the ICTY of being anti-Serb.

21. Acquitted of all charges in March 2016.

22. In 2009, Slovenia blocked Croatia's negotiations on admission to the EU but allowed negotiations to resume after the two countries agreed to submit the dispute to international arbitration.

23. After the democratic changes in 2000, Serbia adopted the Law on the Equalisation of Četniks and Partisans (2004) and rehabilitation of former Četniks (2006).

\section{ORCID}

Ana Milošević (D) http://orcid.org/0000-0003-4479-5397

\section{References}

Baker, Catherine. 2009. "War Memory and Musical Tradition: Commemorating Croatia's Homeland War through Popular Music and Rap in Eastern Slavonia." Journal of Contemporary European Studies 17 (1): 35-45.

Banjeglav, Tamara. 2012. "Conflicting Memories, Competing Narratives and Contested Histories in Croatia's Post-war Commemorative Practices." Politička misao 49 (5): 7-31.

Börzel, Tanja A. 2002. "Pace-Setting, Foot-Dragging and Fence-Sitting: Member State Responses to Europeanization." Journal of Common Market Studies 40 (2): 193-214.

Börzel, Tanja A. 2011. "When Europe Hits ... Beyond its Borders: Europeanization and the Near Abroad." Comparative European Politics 9 (4-5): 394-413.

Clark, Janine Natalya. 2013. "Reconciliation through Remembrance? War Memorials and the Victims of Vukovar." The International Journal of Transitional Justice 7 (1): 116-135.

De Flers, Nicole Alecu, and Patrick Müller. 2009. "Applying the Concept of Europeanization to the Study of Foreign Policy: Dimensions and Mechanisms." Working Paper 5, Vienna: Institute for European Integration Research.

Dnevnik.hr. 2014. "Dan sjećanja na žrtvu Vukovara i Škabrnje obilježen u EP-u." November 18.

Euractiv. 2015. "Croatian MEPs Test their 'firepower' Against Candidate Serbia." March 12.

EP (European Commission). 2005. Eurobarometer EB63, Brussels. http://ec.europa.eu/public_ opinion/archives/eb/eb63/eb63_en.htm.

EP (European Parliament). 2013. Report of Proceedings, P7_CRE-PROV(2013)11-20. 
EP (European Parliament). 2014a. 25th Anniversary of the Fall of the Berlin Wall (debate), P8_CRE$\operatorname{REV}(2014) 11-12$.

EP (European Parliament). 2014b. Serbia: The Case of Accused War Criminal Šešelj, RC-B8-0292/ 2014.

EP (European Parliament). 2015a. Report of Proceedings, P8_CRE-PROV(2015)01-12.

EP (European Parliament). 2015b. Plenary, Report of Proceedings, P8_CRE-PROV(2015)02-09.

Freyburg, Tina, and Solveig Richter. 2010. "National Identity Matters: the Limited Impact of EU Political Conditionality in the Western Balkans." Journal of European Public Policy 17 (2): 263-281.

Geddes, Andrew, and Andrew Taylor. 2015. "Those Who Knock on Europe's Door Must Repent? Bilateral Border Disputes and EU Enlargement." Political Studies 6 (4): 930-947.

HDZ. 2013. "Europski parlament odao počast žrtvama Vukovara." November 19.

HRsvijet. 2014. "HDZ-ovi eurozastupnici reagirali na stavove Martina Schulza: Ignorirate Hrvatsku i pišete hvalospjeve o bivšoj Jugoslaviji." March 19.

Jakovčić, Ivan. 2015. Interview, July 21.

Jelin, Elisabeth. 2003. State Repression and the Labors of Memory. Minneapolis: University of Minnesota.

Jović, Dejan. 2009. “Croatia after Tudjman. The ICTY and Issues of Transitional Justice.” In War Crimes, Conditionality and EU Integration in the Western Balkans, edited by Judy Batt and Jelena Obradović-Wochnik, 13-27. Paris: Institute for Security Studies.

Jović, Dejan. 2012. "The War That is Not Allowed to be Forgotten: Nationalist Discourse on the Homeland War (1991-1995)." Südosteuropa Mitteilungen 3: 52-69.

Krasnec, Tomislav. 2016. "Nije dobro da se SPC nacionalizmom miješa u europski put Srbije." Večernji list, January 13.

Kristović, Ivica. 2013. “Gotovina hodao u koloni pod ruku sa Željkom Jurić.” Večernji list, November 18.

Littoz-Monnet, Annabelle. 2012. "The EU Politics of Commemoration. Can Europeans Remember Together?" West European Politics 35 (5): 1182-1202.

McAllister, David. 2015. Interview, June 17.

MEP EPP 2015 (Member of the European Parliament, European People's Party). 2015. Interview, June 15.

Mink, Georges, and Laura Neumayer, eds. 2013. History, Memory and Politics in Central and Eastern Europe: Memory Games. Basingstoke: Palgrave Macmillan.

Müller, Jan Werner. 2002. Memory and Power in Post-war Europe: Studies in the Presence of the Past. Cambridge: University Press.

Narodne novine. 2000. "Deklaracija o suradnji s Međunarodnim kaznenim sudom u Den Haagu." April 18.

Pavelić, Boris. 2013. "Zabranjena ćirilica u Vukovaru." November 3.

Pavlaković, Vjeran. 2010. "Croatia, the International Criminal Tribunal for the former Yugoslavia, and General Gotovina as a Political Symbol.” Europe-Asia Studies 62 (10): 1707-1740.

Prcela, John Ivan, and Dražen Živić. 2001. Hrvatski Holokaust. Zagreb: Hrvatsko društvo političkih zatvorenika.

Radonić, Ljiljana. 2012. "Croatian Politics of the Past - Just One More Post-Communist Case Study?" Istorija 20. Veka (1): 203-215.

Radoš, Jozo. 2015. Interview, May 26.

Ristić, Marija. 2015. "Croatian MEPs Accuse Serbia of Unjust Prosecutions.” Balkan Transitional Justice, January 20.

Sabalić, Ines. 2015. Interview, July 1.

Schimmelfennig, Frank. 2008. "EU Political Accession Conditionality after the 2004 Enlargement: Consistency and Effectiveness." Journal of European Public Policy 15 (6): 918-937.

Sierp, Aline, and Jenny Wüstenberg. 2015. "Linking the Local and the Transnational: Rethinking Memory Politics in Europe.” Journal of Contemporary European Studies 23 (3): 321-329.

Škrlec, Davor. 2015. Interview, May 28.

Stier, Davor Ivo. 2015. Interview, June 30.

The Guardian. 2012. "War Crimes Convictions of Two Croatian Generals Overturned." November 16.

Tomašić, Ruža. 2015. Interview, May 27. 
Večernji list. 2014. "Nove provokacije: Šešelj četnicima čestitao dan oslobođenja srpskog Vukovara." November 18. Accessed February 4, 2017. http://www.vecernji.hr/svijet/seselj-cetnicimacestitao-dan-oslobodenja-srpskog-vukovara-974182.

Večernji list. 2015. "Dan sjećanja na žrtvu Vukovara i Škabrnje obilježen u EP-u." November 18. Vijesti.hr. 2014. "Ili se radi o licemjerstvu ili žele naštetiti Srbiji." November 27. 